https://helda.helsinki.fi

\title{
A comparison of student teacher learning from practice in university-affiliated schools in Helsinki and Johannesburg
}

\section{Lavonen, Jari}

2019-01-01

Lavonen, J , Henning , E, Petersen , N, Loukomies , A \& Myllyviita , A 2019 , ' A comparison of student teacher learning from practice in university-affiliated schools in Helsinki and Johannesburg ', European Journal of Teacher Education , vol. 42 , no. 1 , pp. 4-18 . https://doi.org/10.1080/02619768.2018.1541083

http://hdl.handle.net/10138/313701

https://doi.org/10.1080/02619768.2018.1541083

acceptedVersion

Downloaded from Helda, University of Helsinki institutional repository.

This is an electronic reprint of the original article.

This reprint may differ from the original in pagination and typographic detail.

Please cite the original version. 


\title{
A comparison of student teachers learning from practice in university- affiliated schools in Helsinki and Johannesburg
}

Jari Lavonen, Elizabeth Henning, Nadine Petersen, Anni Loukomies \& Ari Myllyviita

Cite: To cite this article: Jari Lavonen, Elizabeth Henning, Nadine Petersen, Anni Loukomies \& Ari Myllyviita (2018) A comparison of student teacher learning from practice in university-affiliated schools in Helsinki and Johannesburg, European Journal of Teacher Education, DOI:

$10.1080 / 02619768.2018 .1541083$

\begin{abstract}
In a comparative study of student teachers in Finland and South Africa, the researchers aimed to capture students' views of how and what they had learned from practice in two university-affiliated primary schools. With data from survey questionnaires, we found that students in the two customized programmes accentuated different domains of teacher knowledge. The newly established teaching practice school in Johannesburg afforded closer integration of university and school practicum experiences for students than the wellestablished school in Helsinki. The authors conclude that an innovative teacher education model can be re-invented in a significantly different context, and add new dimensions to the original.
\end{abstract}

Keywords: primary school teacher education; practice-theory integration, achieved curriculum, university-affiliated practice schools, transferring a teacher education model. 


\section{Practice teaching in a university-affiliated training school: Education students and the 'achieved' curriculum}

This paper reports on the findings of research conducted parallel to the establishment of a new teacher training school, on a university campus in Soweto, Johannesburg. This type of school has been part of teacher education in universities in Finland for a long time and is a reminder of Dewey's 'lab school' in Chicago (Harms \& De Pencier, 1996). The Finnish university where this study was conducted founded a 'practice' school in 1972, which has been a model for an innovation at a South African university, where such a school was founded in 2010. The motivation for the inquiry stemmed from the interest of researchers in both settings to find out how students report on their learning outcomes in the practicum periods at the two schools and to compare this self-reporting across two very different institutions. We were interested in how student teachers view the sources of their knowledge (Fives \& Buehl, 2008), also referred to as their 'personal epistemology' (Hofer 2004:1).

At the outset of the inquiry, we regarded each teacher education programme, including its aims or envisaged learning outcomes for different study modules, as the official curriculum, which, together with supporting materials, such as course materials and guidelines, was viewed as the intended curriculum (van den Akker, Fasoglio \& Mulder, 2010). According to Cuban (1992), the intended curriculum organises the body of knowledge and skills that students need to learn and illuminates, at least to some degree, the methods that will be used in teaching (see also DarlingHammond \& Bransford, 2005). Teachers of the programme, who are the university lecturers and school-based mentor teachers in this inquiry, interpret and modify the intended curriculum according to the needs in each context and this evolves into the 
implemented curriculum. This implemented curriculum is thus not necessarily identical to the intended curriculum. The ultimate, achieved curriculum refers to the experiences that are derived from the learning and the teaching processes. This stance resonates with recent research in Norway that postulates a connection between students' beliefs about the sources of knowledge and their motivation for learning (Bråten \& Ferguson, 2015). We captured student views about the achieved curriculum through their reports on what they had learned, taking into consideration the aims of the two teacher education curricula. The analytic framework for the research included interpretations of Shulman's (1987) ideas about types/domains of teacher knowledge by authors such as Arnold, Edwards, Hooley and Williams (2012) and Verloop, van Driel and Meijer (2001), who, along with many others (Fernandez, 2014) theorise teacher knowledge. The following question guided the study: What do student teachers identify as 'domains and sources' of teacher knowledge during supervised practicum in a teaching school?

\section{Domains of Teacher Knowledge}

In this study, the classification of teacher knowledge domains (Shulman, 1986, 1987) provides a framework for analysing and comparing students' views of the achieved curriculum in Helsinki and Johannesburg. A typical approach is thus to divide teacher knowledge into subject-matter (content) knowledge (SMK), pedagogical content knowledge (PCK), and general pedagogical knowledge (GPK) (Carlsen, 1999; Gess-Newsome \& Lederman, 1999; Grossman, 1990; Hashweh, 2005). Shulman's classification (1986, 1987), has been augmented and adapted, for example, by Gess-Newsome and Lederman (1999), who introduced the notion of teachers' contextual knowledge. Contextual knowledge 
encompasses elements such as knowledge about learners and everyday school life, thereby collapsing some of the original Shulman categories.

The intended curriculum refers, also, to content (subject matter) knowledge, which includes conceptual, factual, and procedural knowledge in a given domain, such as mathematics education. A teacher needs to also understand the nature of knowledge - that is, the epistemological and ontological aspects of the subject matter (Shulman, 1987). In the case of early grade teachers, we would argue that different types of teacher knowledge culminate in integrated knowledge of literacy and language, mathematics, and so on, with a strong emphasis on how children learn to learn symbolically (Authors, 2015). We also consider PCK (Carlsen, 1999; Shulman, 1987), being the synthesis of the combined knowledge needed for the teaching of a certain topic. Thus, PCK is always related to subject matter knowledge (Grossman, 1990; Nilsson, 2008). According to Gess-Newsome (1999), the following areas of teacher knowledge have been associated with PCK: (1) teaching or instructional strategies, assessment strategies, and collaboration strategies; (2) knowledge about student interest, motivation, and the learning of conceptual and procedural knowledge and skills; (3) knowledge of learners, such as student thinking, misconceptions, and cognitive and affective demands of tasks and activities; (4) knowledge about resources available to support teaching and scaffold learning; curriculum knowledge and goals for student learning (Abell, Rogers, Hanuscin, Lee, \& Gagnon, 2009). In the European tradition, especially in Germany, France, and the Nordic countries, including Finland, the term 'didactics', or more precisely, 'didactical transformation' (in German, didaktische Transformation), (Kansanen, 2002), captures processes that are similar to those for which a teacher would need PCK domain knowledge 
The third main category of teacher knowledge is GPK (Gore \& Gitlin, 2004), which has a special reference to broad principles and strategies of classroom management and organization that appear to transcend subject matter (Hativa, Barak \& Simhi, 2001; MorineDershimer \& Kent, 1999).

The fourth category described by Gess-Newsome and Lederman (1999) is teachers' contextual knowledge, which includes knowing about who is taught (the learners' dispositions), where teachers teach (classrooms, schools, communities and so on) and what is taught (the subject, level, curriculum and their relationship to local, state and national standards). The ethical, political, economic and social factors that influence teaching in schools are also included in contextual knowledge (Abell \& Lederman, 2007), with contextual knowledge being employed when a teacher utilises different materials and digital learning environments. In the South African context, the authors considered that historical factors, emanating from the long regime of apartheid and segregated schooling, influence contextual knowledge (Author, 2011).

\section{Primary School Teacher Education in Finland and in South Africa}

When the Johannesburg- and Helsinki-based research teams started collaborating in 2012, we scrutinised the two countries' teacher education systems in order to understand the role of the university-affiliated practice (teaching) schools, in the context of the two systems of teacher education (and certification) in which the universities trained teachers. The common denominator of the two programmes is that school personnel and university faculty members work together over the entire duration of a programme of teacher education in a type of 
university-school partnership that explicitly links university education with fieldwork experiences (Peercy \& Troyan, 2017).

In Finland, educational equality is a fundamental value in education and all learners learn in heterogeneous, inclusive classrooms (Jakku-Sihvonen \& Niemi, 2006; Laukkanen, 2008). Decision-making power is decentralized to the local level of the school, and each municipality (district) is responsible for planning the local curriculum, together with teachers, in accordance with the national core curriculum (NCCBE, 2014) and for monitoring the quality of education. Student teachers are thus trained to work in a system, which gives them much autonomy in the classroom. Primary school teaching is a very attractive career choice for young people and at the university in Helsinki only 5\% of applicants are accepted into the programme. Primary school teachers are educated in a five-year master's level programme. The specific practice period in the third year aims to support student teachers to:

- Analyze learning processes and learning environments (GPK);

- Analyze and implement different pedagogical approaches, teaching methods and learning materials while teaching and learning of school subjects (PCK);

- Develop readiness to collaborative planning processes in primary education (PCK);

- Develop readiness to co-teaching and to support different pupils' need in learning (PCK);

- Analyze and reflect own teaching in the context of school curriculum, personal and official aims of teaching practice (PCK).

Pairs of student teachers teach a total of 50 lessons in five different school subjects. They also participate in supervision and reflection sessions with a mentor 
teacher and university lecturer/s. The mentor teachers are regarded as experts in mentoring, while the university lecturer/s are mainly responsible for subject specific planning during a planning week, in which the student teachers also set aims for themselves, explicated in written form. After a lesson has been taught, students reflect as a pair/group with the mentor teacher (Husu, Toom, \& Patrikainen, 2008). Usually these sessions employ a theoretical/conceptual view of the activities that take place in the classroom. At the end of the teaching practice, a final written reflective report on the teaching practice is completed.

In South Africa, the national education department prescribes a single, encompassing national curriculum, the Curriculum Assessment Policy Statement (CAPS) for all primary schools (Department of Basic Education, 2011). The curriculum provides weekly teaching plans for each subject per grade, and strict timelines for completion. The school system is thus highly centralized and teaching is monitored by district officials. The Department of Basic Education (DBE) also uses a number of nationally administered instruments, such as the Annual National Assessments in numeracy and literacy in grades 1-6 and grade 9, to gauge curriculum coverage and to promote accountability in the school sector (Kanjee \& Moloi, 2014).

Historically, primary school teacher education has been an underserved field largely because primary school teachers have been perceived as the lowliest in the hierarchy of teachers (Author, 2011) in the primary school teacher Bachelor of Education degree of four years. Student teachers complete practice teaching periods of between 20 - 32 weeks, over the course of their degree, in various school settings, with the expectation that they will be supervised and formally assessed by practicing teachers and with specific experience in one university-affiliated teaching school. 
With the innovation of such a teaching school on the campus of a Johannesburg university, students now complete the majority of their practice teaching in this school, with the Helsinki university-training school model inspiring the Johannesburg programme. We acknowledge that the transfer of an educational practice from one country and university to another context is relatively difficult, due to the inherent complexity (Elton, 2003) of the intersect of higher education and the public schooling sector in this instance. Therefore, several local adaptations were made in Johannesburg. For example, the university lecturer has a more defined role in the mentoring process than in the Helsinki programme and the teaching practice period was split into shorter periods, spread throughout the year. In particular, the aims for specific courses at the university in Johannesburg and the aims of the teaching practice were aligned more directly than in the Helsinki programme, in order to allow optimal integration of theory and practice.

The Johannesburg students' practicum is organised to include two consecutive block periods in six-week cycles, during which the student teachers observe classrooms, assist, and plan and teach lessons under the supervision of practicing teachers, who are also regarded as student mentors. Students, in groups of 10, prepare lessons, under the guidance of a lecturer at the university, which they teach twice: once as a 'mock lesson' in the first week in a simulation environment and in the week thereafter in the school. A school teacher and a university lecturer together assess the school lesson and provide feedback. Students also assess each other's work. The aims for student learning during the third year of the course are as follows: 
- Identify, recognize and analyze teaching practices in different classrooms (PCK, GPK)

- Analyze how learners' development intersects with the expectations and implementation of the school curriculum (PCK)

- Design and implement age- and grade-appropriate pedagogical approaches and methods accompanied by suitable learning support (PCK, GPK)

- Participate in student group planning for school teaching practice and thus learning to work collaboratively (PCK)

The two programmes have much in common and the investigation was planned to capture similarities and differences as experienced and reported by the student teachers, with the aim of showing how learning in practice resonates with two very different (but also the same) groups of future teachers.

\section{Methods}

A prototype questionnaire, based on the study of literature (Fan \& Yan, 2010; Smith \& Lev-Ari, 2005; Lawson et al, 2015; Cohen (Sayag), Hoz \& Kalan, 2013) and on the aims of the teaching practice in both programmes, as well as tacit knowledge of teacher education, was developed and refined jointly by the research team. In 2014, a prototype questionnaire with several open- and Likert-type questions was prepared, aiming to capture student views of the sources and domains of teacher knowledge which they had been learning in the practicum. There were also several background questions. The second set of questions captured the amount of time used for planning and supervision of teaching practice. The 
third set of questions asked students to show how much teacher knowledge, in various categories, they had gained, using the scale: $1=$ not at all $\ldots 4=$ a lot .

\section{Survey}

The process of designing, refining and piloting the survey items was iterative. The team remained cognizant of the boundaries of what constitutes a 'domain' of teacher knowledge, and of the fluidity of the categories. In the process, we kept in mind that consensus in the team, coupled with 'member checking' with students when we were not sure, resulted in a final questionnaire.

The prototype questionnaire, which was first prepared in English, was tested in a pilot administered in Helsinki $(n=5)$ and in Johannesburg $(n=100)$ with an iterative translation technique used to translate the questionnaire from the original English version into Finnish. Three researchers familiar with the research on teacher knowledge participated in the translation process, which included back-translation.

Five students in both countries were interviewed in order to find out how they interpreted the meaning of the items in the questionnaire. The transcriptions and prototype questionnaires were analysed in a joint workshop with 14 researchers from the two universities. The reliability of the questionnaire was estimated by calculating the Cronbach alpha $(\alpha=0.56)$ using the pilot data $(n=100)$ from Johannesburg. Because the alpha was low, the items were analysed carefully in order to ascertain students' interpretation of the questions. The Johannesburg students, as second 
language English ${ }^{1}$ users, had difficulty in interpreting the meanings of several items and changes were made to accommodate them. For example, we changed the term 'learning community' to 'collaborative lesson planning' as it was closer to students' understanding of their group work. After testing and revising the questionnaire, the Cronbach alpha was higher $(\alpha=0.70)$. The English questionnaire was then finalised and administered in South Africa and the Finnish version in Helsinki.

\section{Data Collection and Analysis}

Helsinki student teachers were asked to participate in the survey voluntarily after the teaching practice period, in $2014-2016.52 \%$ of the students $(n=112)$ responded to the questionnaire. The Johannesburg students completed the survey in the 2014-2-15 period and $70 \%$ of the third year students $(n=100)$ responded.

\section{Statistical analysis}

The scales were interpreted as ordinal. Although the skewness and kurtosis of the distributions were relatively high (skewness $-1.3 \ldots 1.2$ and kurtosis $-1.4 \ldots 1.6$ ) means and standard deviations were calculated in order to compare the responses of student teachers' in Helsinki and in Johannesburg. Statistical significance was analysed with a t-test. However, students in the two contexts awarded different meanings to not at all ... a lot. Therefore, the comparison of students based on the means is not straightforward.

\footnotetext{
${ }^{1}$ South African students usually speak one or more of 11 official languages and for most students, English remains a second or even a third language, although it is the official language of teaching and learning at the Johannesburg university.
} 


\section{Results}

\section{Background Information}

Altogether 106 female- and 123 male students in Helsinki and Johannesburg responded. The third year of teaching practice was selected for the current research because the aims of this practice were somewhat similar in both countries and students had already completed their orientation teaching practice periods. According to the aims of the practicum, the students had to focus on the teaching of various school subjects. $44 \%$ of the Helsinki students and $78 \%$ of the Johannesburg students were classified as full-time students, (employed for less than 30 working hours per week).

\section{Supervision and Student Teachers' Lessons}

In Helsinki, students reported that they had utilised 119 hours during the practicum period of six weeks for planning the lesson and reflecting on the lesson implementation, while the Johannesburg students reported using 279 hours on average. From the data, the South African students reported almost double the time for lesson planning (114 hours) of their Finnish students counterparts (58 hours). In planning time with the university lecturer, the South African students' time was triple (15 hours) that of the Helsinki institution. It is notable, too, that time spent with the mentor teacher differed, with 10 hours in Helsinki and 50 hours on average being reported in Johannesburg. This pattern was visible in the reflective activities, which took up approximately16 hours in a small group; in sessions where mentors assist students in learning from practice students reported spending 12 hours with the university lecturer and 17 hours with mentor teacher in the Helsinki programme. The corresponding hours 
were 51 hours in small groups, 16 hours with the university lecturer and 33 hours with the mentor in the Johannesburg programme.

\section{Student teachers' self-evaluation about their learning during the teaching practice}

Students' evaluations of their learning of different teacher knowledge domains, while they were planning or implementing their lessons, are presented in Tables $1-4$. These selfevaluations could be interpreted as representing the achieved curriculum. The subject matter knowledge (SMK) is captured in Table 1, learning of PCK, while planning or teaching specific content, is presented in Table 2, GPK. Planning or implementing their lessons, features in Table 3 and contextual knowledge about pupils and their families and the school is presented in Table 4.

Table 1. Students reported amount of $\operatorname{SMK}($ Scale: $1=$ not at all $\ldots 4=$ a lot $)$.

\begin{tabular}{|c|c|c|c|c|c|c|}
\hline & \multicolumn{2}{|c|}{ Helsinki } & \multicolumn{2}{|c|}{ Johannesburg } & \multirow[t]{2}{*}{$F$} & \multirow{2}{*}{$\begin{array}{l}p \text {-value } \\
(2- \\
\text { tailed })\end{array}$} \\
\hline & Mean & SD & Mean & $\mathrm{SD}$ & & \\
\hline Mathematics, & 3.33 & 0.79 & 3.37 & 0.86 & 1.6 & .69 \\
\hline Home language and literacy & 0.62 & 1.17 & 2.57 & 1.29 & 140 & .00 \\
\hline $\begin{array}{l}\text { Science (Biology, physics, } \\
\text { chemistry) }\end{array}$ & 1.02 & 1.42 & 0.89 & 1.42 & .84 & .40 \\
\hline Geography & 0.57 & 1.15 & 0.59 & 1.33 & .01 & .91 \\
\hline History & 0.93 & 1.15 & 0.59 & 1.32 & 3.4 & .06 \\
\hline Religious & 1.58 & 1.53 & 0.60 & 1.42 & 24 & .00 \\
\hline Visual art & 1.41 & 1.69 & 0.83 & 1.37 & 24 & .00 \\
\hline $\begin{array}{l}\text { Average reported learning } \\
\text { of SMK }\end{array}$ & 1.32 & & 1.30 & & & \\
\hline
\end{tabular}

Table 2. Students reported amount of PCK learned

$\begin{array}{lllll}\text { Helsinki } & & \text { Johannesburg } & F & \begin{array}{l}p \text {-value } \\ (2- \\ \text { Mean SD } \\ \text { taled })\end{array}\end{array}$


Curriculum knowledge (goals, contents, assessment criteria)

Knowledge about learner interest and motivation.

Setting of goals for teaching and pupil learning.

Teaching and collaboration strategies

Knowledge about resources available to support learning Knowledge of learners' affective (emotional) demands of tasks Knowledge about resources available to support teaching Knowledge about learning of specific concepts

Knowledge about learning of procedural knowledge and skills Knowledge of learners' cognitive demands of tasks

Learners' lack of understanding procedures (such as maths operations)

Knowledge of learner, misconceptions, and lack of understanding of concepts
$3.70 \quad .56$

3.26

.98

16.4

.000

$3.49 \quad .62$

3.30

.97

3.02

.084

$3.36 \quad .69$

3.24

.96

1.04

.309

$3.30 \quad .75$

3.32

.94

.018

.893

$3.23 \quad .69$

$\begin{array}{lll}3.11 & 1.02 & 1.07\end{array}$

.302

$2.92 \quad .78$

2.89

$1.06 \quad .10$

.758

$2.89 \quad .77$

3.15

1.05

4.40

.037

$2.78 \quad .82$

3.25

.08

14.7

.000

$2.75 \quad .79$

2.95

.98

2.72

.100

$2.54 \quad .83$

2.88

$1.07 \quad 7.08$

.008

$2.50 \quad .75$

2.94

$1.00 \quad 14.01$

.000

$2.29 \quad .79$

2.68

1.11

9.10

.003

Average reported learning of PCK 2.98 3.08

Table 3. Students reported amount of GPK learned

\begin{tabular}{|c|c|c|c|c|c|c|}
\hline & \multicolumn{2}{|c|}{ Helsinki } & \multicolumn{2}{|c|}{ Johannesburg } & \multirow[t]{2}{*}{$F$} & \multirow{2}{*}{$\begin{array}{l}\text {-value } \\
(2- \\
\text { tailed })\end{array}$} \\
\hline & Mean & $\mathrm{SD}$ & Mean & $\mathrm{SD}$ & & \\
\hline $\begin{array}{l}\text { Classroom management } \\
\text { and organization. }\end{array}$ & 3.44 & 0.78 & 3.34 & 0.89 & .83 & .363 \\
\hline $\begin{array}{l}\text { Classroom } \\
\text { communication and } \\
\text { discourse }\end{array}$ & 3.44 & 0.69 & 3.30 & 0.89 & 1.80 & .181 \\
\hline $\begin{array}{l}\text { Instructional models and } \\
\text { strategies }\end{array}$ & 3.35 & 0.63 & 3.31 & 0.89 & .15 & 699 \\
\hline $\begin{array}{l}\text { Teaching classes with } \\
\text { diverse learners }\end{array}$ & 3.07 & 0.93 & 3.07 & 1.00 & .00 & .956 \\
\hline $\begin{array}{l}\text { Average reported } \\
\text { learning of GPK }\end{array}$ & 3.33 & & 3.26 & & & \\
\hline
\end{tabular}


Table 4. Students reported amount of contextual knowledge learned

\begin{tabular}{|c|c|c|c|c|c|c|}
\hline & \multicolumn{2}{|c|}{ Helsinki } & \multicolumn{2}{|c|}{ Johannesburg } & \multirow[t]{2}{*}{$F$} & \multirow{2}{*}{$\begin{array}{l}p \text {-value } \\
(2- \\
\text { tailed })\end{array}$} \\
\hline & Mean & SD & Mean & SD & & \\
\hline $\begin{array}{l}\text { Collaborative lesson } \\
\text { planning }\end{array}$ & 3.00 & 1.01 & 3.11 & 1.00 & .72 & .39 \\
\hline $\begin{array}{l}\text { Students' behavioural } \\
\text { problems and how to } \\
\text { address them? }\end{array}$ & 2.89 & 1.06 & 2.78 & .92 & .65 & .42 \\
\hline Teaching large classes & 2.76 & 1.01 & 2.83 & 1.20 & .19 & .660 \\
\hline $\begin{array}{l}\text { Social problems of } \\
\text { learners, }\end{array}$ & 2.70 & 1.12 & 2.65 & .91 & .12 & .73 \\
\hline $\begin{array}{l}\text { Psychological } \\
\text { problems of learners }\end{array}$ & 2.26 & 1.15 & 2.50 & 1.02 & 2.6 & .11 \\
\hline $\begin{array}{l}\text { Family life and health } \\
\text { of children }\end{array}$ & 2.03 & 1.19 & 2.17 & 1.03 & .93 & .34 \\
\hline $\begin{array}{l}\text { Medical problems of } \\
\text { learners }\end{array}$ & 1.55 & 1.17 & 2.16 & .806 & 20.8 & .00 \\
\hline $\begin{array}{l}\text { The effect of poverty } \\
\text { on education }\end{array}$ & 1.45 & 1.16 & 2.38 & .78 & 48.7 & .00 \\
\hline School management & 1.08 & .41 & 2.57 & 1.23 & 143 & .00 \\
\hline School administration & 1.08 & .417 & 2.41 & 1.20 & 118 & .00 \\
\hline $\begin{array}{l}\text { Relationships with the } \\
\text { school districts (SA) or } \\
\text { municipalities } \\
\text { (Finland) }\end{array}$ & 1.17 & .52 & 2.24 & 1.27 & 65 & .00 \\
\hline $\begin{array}{l}\text { Average reported } \\
\text { learning of contextual } \\
\text { knowledge }\end{array}$ & 2.24 & & 2.77 & & & \\
\hline
\end{tabular}

\section{Discussion}

Despite the fact that the practicum format differs in Helsinki and Johannesburg, the questionnaires yielded data that do make a comparison useful for both contexts. The results of the study are discussed around three themes, namely the variance in the learning of PCK and other teacher knowledge types; the juxtaposition of the official, the intended, the 
implemented and the achieved teaching practice curriculum and the transfer of a teacher education model from one well-established programme and a world leading education system to a new programme in a developing country with a weak performance record of education.

Most of the aims in the Helsinki teaching practice curriculum focus on the learning of PCK (Gess-Newsome, 1999; Abell, Rogers, Hanuscin, Lee \& Gagnon, 2009) with students expected to learn about teaching, assessment and collaboration strategies, knowledge of learners, and the curriculum knowledge and resources available to support teaching and to scaffold learning. In terms of GPK, Finnish students should learn to analyse learning processes and learning environments. On the whole, the data from Johannesburg students indicate that they have had a broader (teacher) knowledge exposure than the students from Helsinki. However, since their programme outcomes in the third year place an almost equal emphasis on learning PCK and GPK, there are bound to be some differences.

According to the data, in the Helsinki programme, despite the official curriculum and its aims there is a lack of support for PCK development during practice experience. In Helsinki, the student teachers work in pairs and have a personal, expert mentor teacher who guides the planning and reflection sessions of single lessons. The university lecturers are responsible for reflection leading to the development of PCK. Researchers thus expected that PCK would feature strongly in the student responses. However, university lecturers guided student planning processes for only five hours on average during the period of practice with the result that student teachers in this programme had constructed an achieved curriculum with less PCK than expected. We agree with Husu, Toom and Patrikainen (2008) that Finnish student teachers can use various kinds of reflection in order to learn from 
practice if they are guided to do this. Finnish students did however, report that they gained contextual knowledge and they learned to plan lessons collaboratively which is in line with the Helsinki curriculum's emphasis on planning processes.

In contrast, the practicum in Johannesburg seems to support the learning of PCK amply. The data shows much higher values of specific areas of PCK development. The mentor teacher and university lecturer guide student teachers' planning processes with the total time planning amounting to almost three times that of the Finnish programme. There is also a significant difference in the knowledge of the resources available to support teaching and learning, of learners' affective and cognitive demands of their tasks and of learning specific concepts. This may be due to the very strong emphasis on child development studies in which a university student studies the progression of one child over three years of the programme. This is a unique aspect of the Johannesburg model and is a feature of many assessment tasks in the programme.

Surprisingly, the students at both institutions did not mention much SMK, except in reference to mathematics. Even though the aim of the practicum is not to develop SMK, we still find it strange that school subject knowledge was not more prominent in the data, especially since the South African students are generally in need of much subject content enrichment (Authors, 2015). One area where there is a noticeable difference between the two groups is in the learning of home language and literacy with the Johannesburg students reporting more learning. Having noted this, we again need to acknowledge that comparison between students from different contexts, in which they, furthermore, self-report, requires careful consideration. It may be, for example that they interpreted the scale differently. It may also be the South African system of home language of teaching in one of 11 official languages from pre-school to Grade 3 with learners switching to English as language of 
teaching in Grade 4. Many national studies report on learners struggles with this and it is an aspect that receives much attention in university coursework.

The data from this study shows that in the official curriculum, the teacher educators, in collaboration with mentor teachers in the school, design a practicum programme for optimal learning. And yet, the end result is, as much of the literature is witness to, that students learn optimally from practice when their experiences are also aligned to methods courses at the university (Ronfeldt et al, 2014). This is what the Johannesburg data supports. In a study of newly graduated teachers in South Africa, Author (2011) found that student teachers needed to have a say in the design of their education. It however remains a contested space, even in conditions that are optimal, such as those in a teaching school that works very closely with the university programme. We believe that it is an aspect that needs much more investigation, perhaps through an analysis of the interactions between mentor teachers, lecturing staff and students, if we are to make evidence-based claims about the value of the practicum for effective instruction. In a recent study of teacher preparation using graduates' observational ratings, Ronfeldt and Campbell (2016) propose that observation of new teachers need to be added to the self-reporting methods used to explore (and measure) what student teachers are learning.

From the migration of the model of teacher education from a university in Helsinki to a university in South Africa, we have learned much. We conclude that when students are able to integrate theory and practice in a synchronized way, they do learn increasingly from practice. This is likely because the university curriculum in Johannesburg coincides harmoniously with the practicum and it continues over the entire duration of the programme. The integration is more streamlined than the 
Finnish model, with student teachers 'moving up' in the school system over four years and getting acquainted with the learners as they develop, with the school and its community. This is evident in the differences between the two groups in Table 4. Johannesburg students report learning more about learners' medical problems and the effect of poverty on education. This is not unsurprising given the economic inequity of South African society and the strong coursework emphasis on learning how poverty affects educational provisioning. Students will also have observed this closely in the school, as their study of young learners is a four-year long relationship. University-learned theory thus links with practice immediately, as it happens, and is sustained over the duration of the degree. In addition, in South Africa, with its highly centralised and monitored educational environment, students will be much more aware of school management and administration. This is also a prominent component of university coursework, providing some evidence of the value of coupling university coursework with observations in a teacher training school.

In the Johannesburg programme more time is also allocated for planning and reflection and for piloting lessons in a simulated form of 'mock' teaching with fellow students - before venturing into the school. This aspect is better planned possibly because the programme designers know the dire educational needs of the students, most of whom did not have good teacher role models (Lortie, 1978).

Overall, we learned that the transfer of a teacher education model from one country to another is challenging (Elton, 2003), but possible if the 'adopting' country takes into consideration its own context and modifies the model according to local needs. Actually, in this case, based on the student reporting data, the emerging model in the Johannesburg programme holds pointers for improving the original Helsinki model. We agree with Lillejorda and Børtea (2016) that the work structures are not enough for student teachers to 
learn from practice. We would argue that the learning depends more on the relational partnerships between the university department with its university lecturers and the teacher training school with its mentor teachers. In practice the support of university lecturers and mentor teachers do depend on how the learning environment is structured, how responsibilities are defined and how the work is divided. However, the relationships and harmony between the two role layers is equally important. Our study ended with the encouraging conclusion that transporting a model to a different context can synthesize two realities in such a way that both can benefit from the findings.

\section{Conclusion:}

The development of the teaching practicum at the primary school in Soweto has taken its own course, deviating from the Finnish model - and not only for obvious reasons of the 'architecture of practices' (Kemmis \& Grootenboer, 2008: 38) and the bigger picture of learning to be a teacher in a very different context (Baker \& LeTendre, 2005). Lieberman and Mace (2010:77) in their discussion of teacher education for the $21^{\text {st }}$ century, argue that a 'resurgence of practice theories are crucial'. We argue that with the growing internationalization of educational research, findings from studies that include different educational traditions, languages and culture are crucial for generalising and theorising from findings. We also agree with what Schatzki (2001) and, Kemmis et al. (2014), that a practice view makes it possible to see practice from a site-based perspective, which is, in effect, an ontological perspective. An ontological approach would emphasise that practices occur and are enmeshed within particular kinds of nuanced arrangements found at specific sites, like particular classrooms in particular schools in particular communities. In South Africa, the nuances of the particular environment of a university in Johannesburg, in the 'township' of 
Soweto, were the driving force in amending the programme to suit local needs. As the first teacher education programme with a firm footing in an affiliated practice school, a new model has emerged in South Africa, that may even have augmented the original model with some useful ideas for improving the practicum in the North.

\section{References}

Abell, S., Rogers, M. P., Hanuscin, D. L., Lee, M. H., \& Gagnon, M. J. (2009). Preparing the next generation of science teacher educators: A model for developing PCK for teaching science teachers. Journal of Science Teacher Education, 20(1), 77-90.

Arnold, J., Edwards, T., Hooley, N., \& Williams, J. (2012). Conceptualising teacher education and research as critical praxis. Critical Studies in Education. 53(3), 281295.

Baker, D. P., \& LeTendre, G. K. (2005). National differences, global similarities: World culture and the future of schooling. Stanford, CA: Stanford University Press.

Bråten, I., \& Ferguson, L.E. (2004). Beliefs about sources of knowledge predict motivation for learning in teacher education. Teaching and Teacher Education. 50, 13-23.

Carlsen, W. (1999). Domains of teacher knowledge. In J. Gess-Newsome \& N. G. Lederman (Eds.), Examining pedagogical content knowledge: The construct and its implications for science education (pp. 133-144). Dordrecht: Kluwer Academic Publishers.

Cohen (Sayag), E., Hoz, R \& Kaplan, H. (2013) The practicum in preservice teachereducation: a review of empirical studies, Teaching Education, 24(4), 345-380. 
Cuban, L. (1992). Curriculum stability and change. In P. Jackson (Ed.), Handbook of Research on Curriculum. New York: American Educational Research Association.

Darling-Hammond, L., \& Bransford, J. (2005). Preparing teachers for a changing world: What teachers should learn and be able to do. San Francisco, CA: Jossey-Bass.

Elton, L. (2003). Disseminations of Innovations in Higher Education: A Change Theory Approach. Tertiary Education and Management, 9(3), 199-214.

Fan, W., \& Yan, Z. (2010), Factors affecting response rates of the web survey: A systematic review, Computers in Human Behaviour, 26(2), 132-139.

Fernandez, C. (2014). Knowledge base for teaching and pedagogical content knowledge (PCK): some useful models and implications for teachers' training. Problems of Education in the $21^{\text {st }}$ Century. 60, 79-99.

Fives, H., \& Buehl, M. M. (2008). What do teachers believe? Developing a framework for examining beliefs about teachers' knowledge and ability. Contemporary Educational Psychology, 33,134-176.

Authors, (2015) [details removed for peer review]

Gess-Newsome, J. (1999). Pedagogical content knowledge: An introduction and orientation. In J. Gess-Newsome \& N. G. Lederman (Eds.), Examining pedagogical content knowledge: The construct and its implications for science education (pp. 3-17). Dordrecht: Kluwer Academic Publishers. 
Gess-Newsome, J., \& Lederman, N. G. (Eds.). (1999). Examining pedagogical content knowledge: The construct and its implications for science education. Dordrecht: Kluwer Academic Publishers.

Gore, J., \& Gitlin, A. (2004). [Re]visioning the academic-teacher divide: Power and knowledge in the educational community. Teachers and Teaching: Theory and Practice, 10(1), 3558.

Grossman, P. (1990). The making of a teacher. Teacher knowledge and teacher education. New York: Teachers College Press, Columbia University.

Harms, W. \& De Pencier, I. (1996). 100 Years of learning at the University of Chicago Laboratory Schools. (http://www.ucls.uchicago.edu/d2012ata/files/gallery/HistoryBookDownloadsGallery/ chapter1_3.pdf). Accessed on 1 October 2013.

Hashweh, M. (2005). Teacher pedagogical constructions: A reconfiguration of pedagogical content knowledge. Teachers and Teaching: Theory and Practice, 11(3), 273-292.

Hativa, N., Barak, R., \& Simhi, E. (2001). Exemplary university teachers: Knowledge and beliefs regarding effective teaching dimensions and strategies. The Journal of Higher Education, 72(6), 699-729.

Hofer, B. K. (2004). Introduction: paradigmatic approaches to personal epistemology. Educational Psychologist, 39, 1-3.

Authors, (2011) [details removed for peer review] 
Husu, J., Toom, A., \& Patrikainen, S. (2008). Guided reflection as a means to demonstrate and develop student teachers' reflective competencies, Reflective Practice, 9(1), 37 51.

Jakku-Sihvonen, R., \& Niemi, H. (2006). The Bologna process and its implementation in teacher education. In R. Jakku-Sihvonen \& H. Niemi (Eds.), Research-based teacher education in Finland - Reflections by Finnish teacher educators (pp. 17-50). Turku: Finnish Educational Research Association.

Kanjee, A., \& Moloi, Q. (2014). South African teachers' use of national assessment data. South African Journal of Childhood Education. 4(2), 90-113.

Kansanen, P. (2002). Didactics and its relation to educational psychology: Problems in translating a key concept across research communities. International Review of Education, 48(6), 427-441.

Kemmis, S., \& Grootenboer, P. (2008). Situating praxis in practice. In S. Kemmis \& T. Smith (Eds.), Enabling praxis: Challenges for education (pp.37-64). Rotterdam: Sense Publishers.

Kemmis, S., Wilkinson, W., Edwards-Groves, C., Hardy, I., Grootenboer, P., \& Bristol, L. (2014). Changing Practices, Changing Education. London: Springer.

Laukkanen, R. (2008). Finnish strategy for high-level education for all. In N. Soguel \& P. Jaccard (Eds.), Governance and performance of education systems (pp. 305-324). AA Dordrecht, The Netherlands: Springer. 
Lawson, T., Çakmak, M, Gündüz, M., \& Busher. H. (2015). Research on teaching practicum - a systematic review, European Journal of Teacher Education, 38(3), 392-407.

Lieberman, A., \& Mace, D. P. (2010). Making practice public: Teacher learning in the $21^{\text {st }}$ century. Journal of Teacher Education, 61(1-2), 89-99.

Lillejorda, S., \& Børtea, K. (2016). Partnership in teacher education - a research mapping. European Journal of Teacher Education. 39(5), 550-563.

Lortie, D. 1975. Schoolteacher: A sociological study. Chicago: University of Chicago Press.

Morine-Dershimer, G., \& Kent, T. (1999). The complex nature and sources of teachers' pedagogical knowledge. In J. Gess-Newsome \& N. G. Lederman (Eds.), Examining pedagogical content knowledge: The construct and its implications for science education (pp. 21-50). Dordrecht: Kluwer Academic Publishers.

NCCBE (2014). The National Core Curriculum for Basic Education. Helsinki: National Board of Education. Retrieved from http://www.oph.fi/ops2016.

Nilsson, P. (2008). Teaching for understanding: The complex nature of pedagogical content knowledge in pre-service education. International Journal of Science Education, 30(10), 1281-1299.

Authors (2014). [details removed for peer review]

Ronfeldt, M., \& Campbell, S.L. (2016). Evaluating teacher preparation using graduates' observational ratings. Educational Evaluation and Policy Analysis, 38(4), 602-625. 
Ronfeldt, M., Schwartz, N., \& Jacob, B.A. (2014). Does Pre-service Preparation Matter? Examining an Old Question in New Ways. Teachers College Record, 116(10), 1-46.

Schatzki, T. R. (2001) Introduction: practice theory. In Schatzki, T.R., Cetina, K.K. \& von Savigny, E. The practice turn in contemporary theory. London: Routledge.

Shulman, L. S. (1986). Those who understand: Knowledge growth in teaching. Educational Researcher, 15(2), 4-14.

Shulman, L. S. (1987). Knowledge and teaching: Foundations of new reform. Harvard Educational Review, 57, 1-22.

Smith, K. \& Lev-Ari, L. (2005). The place of the practicum in pre-service teacher education: the voice of the students, Asia-Pacific Journal of Teacher Education, 33(3), 289-302.

van den Akker, J., Fasoglio, D., \& Mulder, H. (2010). A curriculum perspective on plurilingual education. Preliminary study for the document "Guide for the development and implementation of curricula for plurilingual and intercultural education". Netherlands: Council of Europe.

Verloop, N., Van Driel, J., \& Meijer, P.C., (2001). Teacher knowledge and the knowledge base of teaching. International Journal of Educational Research. 35(5), 441- 461. 